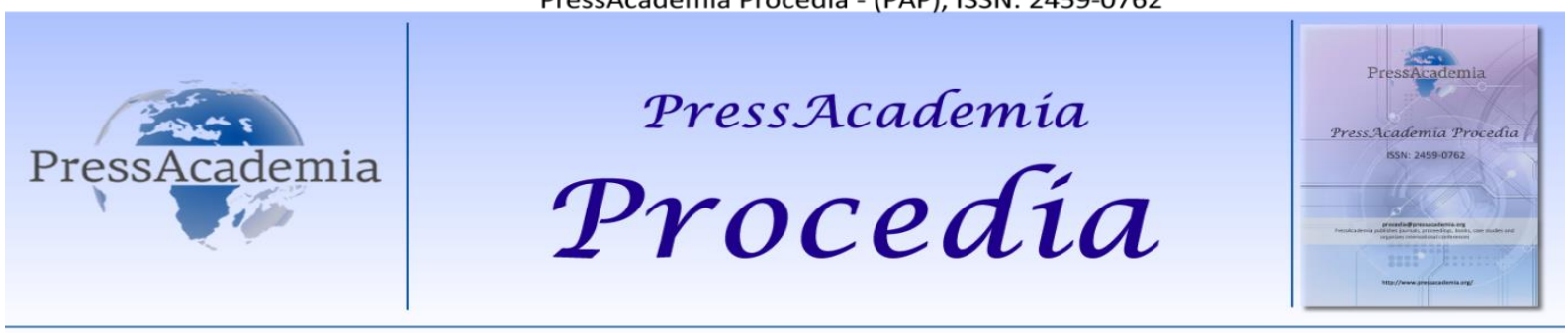

Global Business Research Congress (GBRC), May 24-25, 2017, Istanbul, Turkey

\title{
DETERMINATION OF THE RELATIONSHIP BETWEEN THE CONSUMERS REASONS FOR PREFERENCE OF SHOPPING CENTERS: APPLICATION OF ERZURUM
}

\author{
DOI: 10.17261/Pressacademia.2017.642 \\ PAP- GBRC-V.3-2017(68)-p.666-673
}

\author{
Dilsad Guzel ${ }^{1}$, Ibrahim Kadir Demir ${ }^{2}$, Fatma Gul Yazicilar ${ }^{3}$ \\ ${ }^{1}$ Atatürk Üniversitesi ilBF, Erzurum, Türkiye, dguzel@atauni.edu.tr \\ ${ }^{2}$ Ağrı İbrahim Çeçen Üniversitesi ï̈BF, Ağrı, Türkiye kadir.demir29@gmail.com \\ ${ }^{3}$ Hamza Polat MYO, Erzurum, Türkiye , f.yazicilar@atauni.edu.tr
}

\section{To cite this document}

Guzel D, I. K. Demir and F. G. Yazicilar (2017). Determination of the relationship between the consumers reasons for preference of shopping centers: application of Erzurum. PressAcademia Procedia (PAP), V.3, p.666-673.

Permemant link to this document: http://doi.org/10.17261/Pressacademia.2017.642

Copyright: Published by PressAcademia and limited licenced re-use rights only.

\begin{abstract}
Retail businesses are the most important element of the channel of distribution when their closeness to consumers is considered. With the increasing urbanization, shopping center retailing in which several brands and products are gathered in a closed areas shown up in addition to street retailing, the number of conventional street shops have gradually decreased. Shopping centers, which were once located in big cities, have become widespread even in small towns these days. In this study, a survey was taken a poll for customer who lived in Erzurum. Survey data were analyzed with by means of SPSS.20 packaged software. The reasons why consumers prefer shopping centers and the relations between these reasons are determined and the results are interpreted.
\end{abstract}

Keywords: Malls, Consumer Preferences, Consumer, Preference, Shoping

JEL Codes: M39, M31, M30

\section{TÜKETICILERIN ALIŞVERIŞ MERKEZLERINi TERCiH ETME NEDENLERi ARASINDAKi íLişKININ BELIRLENMESI: ERZURUM ILI UYGULAMASI}

\section{ÖZET}

Tüketiciye yakınlığı düşünüldüğünde perakendeci işletmeler dağııım kanalının en önemli unsurudur. Şehirleşmenin artmasıyla birlikte cadde mağazacılığının yanında kapalı alanda birden fazla marka ve ürünün bir araya getirildiği alışveriş merkezi mağazaclığı ortaya çıkmıştır. Bununla birlikte, klasik cadde mağazaları birer birer azalmıştır. Önceleri büyük şehirlerde yer alan alışveriş merkezleri şimdilerde ilçelerde bile yaygın hale gelmiştir. Çalışma kapsamında, Erzurum ilinde bulunan alışveriş merkezlerindeki müşterilere anket uygulanmış, anket verileri SPSS.20 paket programı yardımıyla analiz edilerek tüketicilerin alışveriş merkezlerini tercih etme sebepleri ve bu sebepler arasındaki ilişkiler belirlenmiş ve sonuçlar yorumlanmıştır.

Anahtar Sözcükler: Alışveriş Merkezler, Tüketici Tercihleri, Tüketici, Tercih, Alışveriş JEL Kodları: M39, M31, M30

\section{GíRiş}

Insan ihtiyaçlarının karşılanması olarak tanımlanan tüketim kavramı, iktisadi bir kavram olmakla birlikte farklı ülkelerin ve toplumların benimsedikleri sosyal ve kültürel unsurlara göre farklılık gösteren, çağın şartlarına göre değişen toplumsal bir olgudur (Beylü,1982:413). Tüketici davranışları ise insan davranışlarının alt bölümüdür ve anlaşılıp anlamlandırılabilmesi için bireyin çevresiyle olan etkileşimi baz alınarak hareket edilmelidir (Pekgüleç, 2003). Bireylerin tüketim davranışı, bireylerin mal ve hizmetleri tüketimine sebep olan kararlar süreci olarak da tanımlanabilir (Tek, 1999). Bireylerin tüketim davranışı, güdülenmiş bir davranış olması, çeşitli faaliyetlerden oluşması, kompleks olması, zaman açısından farklıık göstermesi, 
çevresel uyarıcılarla yakından ilişkili olması ve dinamik bir süreç olması gibi özelliklere sahiptir (Odabaşı ve Barış, 2002). Tüketiciler intiyaç duydukları mal ve hizmetleri tüketici pazarından temin ederler. Mal ve hizmetlerin tüketiciye ulaşmasını sağlayan ise perakendecilerdir (Akat, 2004). Perakendecilik, eşya ve servislerin ticari amaç olmaksızın nihai tüketiciye, kişisel işlerinde kullanması için yapılan faaliyetlerin tamamıdır (Kotler, 2000;520). Ürünlerin, nasıl satıldığının ya da nerede satıldığının bir önemi yoktur. Son tüketiciye yapılan satışların tamamı perakende satıştır (Kotler ve Keller,1997:504). Tüketicilere satılan mal ve hizmetlere işletmeler bir değer kattığından perakendecilik işletme faaliyetlerinin bir parçasıdır (Aydın, 2007:8). Cadde mağazacılığının yıllar boyunca çalışarak oluşturduğu müşteri portföyü, AVM mağazacılığının ise sosyal imkânların genişliği ve sağladığı fiziksel kolaylıklar tüketiciyi bu ikisi arasında tercih yapmaya yöneltmiştir. Bu sebeple her iki yerdeki girişimci için kuruluş yeri seçimi hayati derecede önemlidir. Bu seçimi yaparken hata yapmamak büyük önem taşımaktadır. (David, 2007: 73). Bu doğrultuda çalışmada, tüketicilerin alışveriş için AVM' leri tercih etme sebepleri araştırılarak, Erzurum ili şehir merkezinde faaliyet gösteren AVM' leri tercih etmelerinde etkili olan faktörler arası ilişkiler saptanmaya çalışılmıştır. Çalışma 2 bölümden oluşmaktadır. Giriş bölümünden sonra birinci bölümde AVM mağazacılığına değinilmiş, ikinci bölümde ise; uygulama kısmına geçilmiştir. Uygulama kısmında anket yöntemi kullanılmış ve veriler SPSS 20.00 paket programı ile analiz edilerek sonuç kısmı oluşturulmuştur.

\section{ALIŞVERIŞ MERKEZI(AVM) MAĞAZACILIĞI KAVRAMI}

İnsanoğlunun temel eylemlerinde birisi olan alışveriş, önceleri şehir merkezinde meydana gelen sosyal bir olguydu (Birol, 2005:63-75). Şehir merkezinde gerçekleşen bu eylem 19.yy ın sonlarına doğru, modern alışveriş merkezlerinin temeli olan, büyük mağaza ve pasajlara doğru yönelmiştir (White, 2001:65-80). Zamanla sosyal yaşamda meydana gelen farklılıklar, kültürel değişim ve artan gelir ile insanların tüketim davranışlarında değişiklikler olmuş, gün geçtikçe insanların alışverişe ayırdığı zaman azalmış ve bütün ihtiyaçların bir seferde karşılanmasına olanak veren AVM' lerin hayatımızdaki önemi giderek artmıştır (Ekinci vd., 1999: 110). Çeşitli yazarlar AVM ler için birbirinden farklı birçok tanım yapmışlardır. Bu tanımlardan yola çıkarak AVM' ler için “planlanmış, geliştirilmiş ve içerisinde küçüklü büyüklü birçok perakendecinin bulunduğu, 5.000-300.000 metrekare aralığında alana sahip olan ve tek bir mülk gibi yönetilen komplekslerdir" tanımını yapmak mümkündür (Alkibay vd., 2007: 2). Yapılan literatür taraması sonucunda günümüz AVM'leri, tüketicilerin iklim şartlarından etkilenmediği, kendini güvende hissettiği ve alışverişlerinin sonucunda haklarının nispi olarak daha fazla korunduğu bir tüketim imkânı sunarak geleneksel alışverişden ayrılmaktadır. Bu sebeple tüketici ihtiyaçlarını sistematik bir yapı içerisinde çağdaş bir anlayışla karşılamayı amaçlayan komplekslere modern AVM denilmektedir.

Modern AVM' ler, bir grup perakendeci ile çeşitli ticari birimlerin tek bir mülkiyet altında planlanması, geliştirilmesi, sahiplendirilmesi ve yönetilmesidir (Levyve Weitz,2004:218). AVM tasarımlarında ön planda tutulan ana düşünce, potansiyel müşterinin tercihi olmak ve sonrasında tüketiciyi mümkün olduğunca uzun süre tutarak harcama yapmasını sağlamaktır (Önbilgin ve Uzun, 2002:23). Bunun için ise; tüketicinin ihtiyaç duyabileceği herşeyi mekândan dışarı çıkmadan temin edebilmesi gerekmektedir. Örneğin bebek emzirme ve bebek bezi değiştirme odaları, küçük çocuklu annelerin karşılanması gereken temel ihtiyaçlarındandır (Azhari vd., 2012). Alışveriş merkezleri mağaza, market, banka, pastane, kafeterya, sinema, güvenlik ve otopark gibi imkânların hepsine aynı anda ulaşabilme olanağı sağlayan mekânlardır (Altunışık ve Mert, 2007). Birçok ihtiyacı aynı anda karşılama avantajına sahip olan AVM'ler, tüketime yılın her gün ve saatinde imkân veren mekânlardır (Süer ve Sayar, 2002:39). İnsanları tüketime yönelten şey, ihtiyaçlarını karşılama gereksiniminin yanında kişisel ve sosyal güdüleridir. Ancak tüketicilerin AVM'leri tercih etmelerinde ürün çeşitliliği, sunulan hizmetin kalitesi ve daha bir çok etkenin rolü bulunmaktadır (Arslan, 2004). Bunun sonucunda AVM' ler insanların alışveriş yapmak için geldikleri bir yer olmaktan çıkmış ve sosyo-kültürel bir misyon görevi üstlenmiştir. Alışveriş için birçok yeri tercih edebiliyor olmasına rağmen AVM' lerde alışveriş yapmayı seçen tüketiciler, harcama yapsın ya da yapmasın, alışveriş yapmanın ötesinde statü belirleme, gösteriş, haz alma ve kendini kanıtlama gibi birçok misyon üstlenmiştir (Torlak, 2007:146).

\section{ERZURUM ŞEHIR MERKEZINDE BIR UYGULAMA}

\subsection{Araştırmanın Amacı ve Kapsamı}

Bu çalışmanın amacı, tüketicilerin alışveriş için $A V M^{\prime}$ leri tercih etme sebeplerini araştırarak, Erzurum ilinde şehir merkezinde faaliyet gösteren AVM' leri tercih etme davranışları hakkında genel bir çerçeve çizmek ve tüketici tercihlerinde etkili olan faktörler arası ilişkileri ortaya koymaktır. Araştırmanın kapsamını Erzurum ilindeki AVM müşterileri oluşturmaktadır.

\subsection{Araştırmanın Yöntemi}

Bu çalışmada, birincil veri toplama yöntemlerinden biri olan anket yöntemi kullanılmıştır. Bu doğrultuda literatür taraması yapılarak anket soruları oluşturulmuştur. Anketler Erzurum şehir merkezinde bulunan Erzurum AVM ve Palerium AVM'yi ziyaret eden 385 müşteriye birebir uygulanmıştır.

Anket formu iki bölümden oluşmaktadır. Birinci bölümde demografik özellikler, diğer bölümde ise $5^{\prime} l i$ Likert ölçeği kullanılarak tüketicilerin alışveriş için AVM' leri tercih etme sebeplerini içeren sorular bulunmaktadır. Bu doğrultuda elde edilen veriler SPSS.20 paket programı aracılığı ile analiz edilerek, elde edilen sonuçlar yorumlanmıştır. 


\subsection{Araştırmanın Analiz ve Bulguları}

\section{Ankete Katılan Tüketicilerin Demografik Özellikleri}

Anket sonucu elde edilen veriler, SPSS 20.00 paket programı yardımıyla gerekli analizlere tabi tutulmuş, yapılan frekans analizi sonucunda işletmelerin demografik özellikleri Tablo 1'de gösterilmiştir.

Tablo 1: Demografik Özellikler

\begin{tabular}{|c|c|c|c|}
\hline & & $\begin{array}{c}\begin{array}{c}\text { Frekans } \\
\mathbf{N}=385\end{array} \\
\end{array}$ & Yüzde \% \\
\hline \multirow{4}{*}{ Yaş } & 21-30 Yaş Arası & 377 & 97,9 \\
\hline & 31-40 Yaş Arası & 6 & 1,6 \\
\hline & 41-50 Yaş Arası & 1 & 0,25 \\
\hline & 61 ve Üzeri & 1 & 0,25 \\
\hline \multirow[t]{2}{*}{ Cinsiyet } & Bay & 138 & 35,8 \\
\hline & Bayan & 247 & 64,2 \\
\hline \multirow{3}{*}{ Medeni Durum } & Evli & 8 & 2,1 \\
\hline & Bekar & 370 & 96,1 \\
\hline & Boşanmış & 7 & 1,8 \\
\hline \multirow{4}{*}{ Eğitim Durumu } & Ortaokul & 1 & 0,3 \\
\hline & Lise & 19 & 4,9 \\
\hline & Üniversite & 353 & 91,7 \\
\hline & Y.Lisans/Doktora & 12 & 3,1 \\
\hline \multirow{6}{*}{ Gelir } & 500 TL den az & 56 & 14,5 \\
\hline & $500-1000 \mathrm{TL}$ & 80 & 20,8 \\
\hline & $1001-2000 \mathrm{TL}$ & 83 & 21,6 \\
\hline & 2001-3000 TL & 90 & 23,4 \\
\hline & $3001-4000 \mathrm{TL}$ & 37 & 9,6 \\
\hline & 4000 TL ve üzeri & 39 & 10,1 \\
\hline \multirow{4}{*}{$\begin{array}{l}\text { AVM'in Ziyaret Edildiği } \\
\text { Günler }\end{array}$} & Hafta içi & 11 & 2,9 \\
\hline & Hafta sonu & 119 & 30,9 \\
\hline & Hem hafta içi hem hafta sonu & 48 & 12,5 \\
\hline & Belirli bir gün yok & 207 & 53,7 \\
\hline \multirow{5}{*}{ AVM'de Kalma Süresi } & 30 dakikadan az & 50 & 13,0 \\
\hline & 31-60 dakika & 121 & 31,5 \\
\hline & 61-90 dakika & 91 & 23,6 \\
\hline & 90-120 dakika & 81 & 21,0 \\
\hline & 121 dakikadan daha fazla & 42 & 10,9 \\
\hline
\end{tabular}

Çalışmaya toplamda, Forum ve Palerium AVM de alışveriş yapan 385 kişi katılmakta olup, örnekleme ait frekans dağılımları Tablo 1 'de görüldüğü üzere şu şekildedir. Araştırmaya katılıp anket sorularını cevaplayan katılımcıların yaklaşık \%98'i 21-30 yaş aralığında olmakla birlikte yaklaşık \%64' ü bayandır. Katılımcıların yaklaşık \%96 'sı bekar ve \%92'si üniversite mezunudur ve gelirleri \%23,4 oranla 2001-3000 TL arasındadır. Tüketicilerin AVM leri ziyaret ettikleri günler \%53,5'lik oranla belirli bir gün değilken, \% 30,9'luk oranla hafta sonlarıdır ve katılımcıların \%31,4' ü AVM de 31-60 dakika arasında vakit geçirmektedir.

Müşterilerin, AVM 'leri tercih etme nedenlerinin belirlenmesine yönelik sorulara verdikleri cevapların birbirleri ile ilişkili olup olmadığının saptanmasına yönelik yapılan ki-kare test istatistiği sonuçları Tablo 2' de gösterilmiştir. 
Tablo 2: Çapraz Tablo Sonuçları (Pearson Ki-Kare İstatistikleri)

\begin{tabular}{|c|c|c|c|c|c|c|c|}
\hline & $\stackrel{\mathbb{m}}{2}$ & 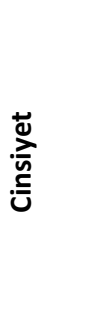 & $\stackrel{\underline{E}}{\underline{\underline{E}}}$ & 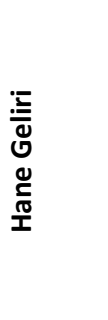 & 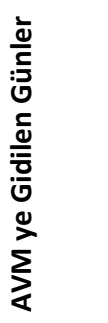 & 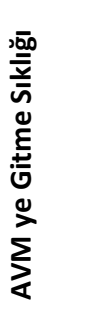 & 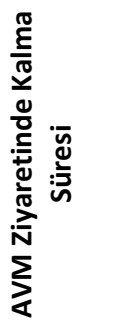 \\
\hline $\begin{array}{l}\text { Çarşıda bulunmayan } \\
\text { mağazaların olması }\end{array}$ & - & - & - & - & - & ,024* & ,015* \\
\hline $\begin{array}{l}\text { Ücretsiz dinlenme alanlarının } \\
\text { olması }\end{array}$ & ,048* & ,017* & - & ,030* & - &, $097^{* *}$ & ,012* \\
\hline Kafe ve restoranların olması & - & - & ,014* & - & - & - & ,020* \\
\hline AVM de süpermarket bulunması & - & - & $015^{*}$ & - & - & - & $027^{*}$ \\
\hline Kalabalık olması & - & - & - & ,032* &, $061 * *$ & - & ,016* \\
\hline Ünlü mağazaların olması & - & ,034* & - & - & - & - & - \\
\hline Asansör olması & - & - & - & - & - & - & ,020* \\
\hline $\begin{array}{l}\text { Kışın soğuktan, yazın sıcaktan } \\
\text { korunma imkânının olması }\end{array}$ & - & ,001* & - & - & - & - & ,010* \\
\hline $\begin{array}{l}\text { AVM'nin temiz ve düzenli } \\
\text { olması }\end{array}$ & - & - & ,019* & - & - & ,020* & - \\
\hline $\begin{array}{l}\text { Güvenlik görevlilerinin olumlu } \\
\text { tutum ve davranışları }\end{array}$ & - & - &, $027^{*}$ & - & - & - & - \\
\hline TV yayınının olması & - & - & - & - & - & - & ,038* \\
\hline Ziyaretçilerin kalma süresi & - & - & - & ,050* & - & - & - \\
\hline $\begin{array}{l}\text { Harcanan paranın karşılığının } \\
\text { alındığı düşüncesi }\end{array}$ & - & - & - &, $068^{* *}$ & - & - & ,055** \\
\hline $\begin{array}{l}\text { AVM de satış ve } \\
\text { promosyonlarının yapılması }\end{array}$ & - & - & - &, $057^{* *}$ & - & - & - \\
\hline Ferah ve kolay gezilebilir olması & - & - & - & - & - & - & - \\
\hline Sinema salonunun olması & - & - & - & - & - & - & - \\
\hline $\begin{array}{l}\text { Çalınan müziklerin zevkime } \\
\text { uygun olması }\end{array}$ & - & - & - & - & - & - & - \\
\hline $\begin{array}{l}\text { Genel olarak fiyatların düşük } \\
\text { olması }\end{array}$ & - & - & - & - & ,029* & - & - \\
\hline Kolay ulaşılabilir olması & - & - & - & - & - &, $087^{* *}$ & ,000* \\
\hline Güvenlik hizmetinin olması & - & - & - & - & - & - &, $068 * *$ \\
\hline $\begin{array}{l}\text { Çok çeşitli mağazalara sahip } \\
\text { olması }\end{array}$ & - & - & - & - & - & - & $084 * *$ \\
\hline Satış elemanlarının davranışları & - & - &, $072 * *$ & - & - & - & - \\
\hline Kaliteli ürünlerin olması & - & - & - & - & - & - & ,001* \\
\hline $\begin{array}{l}\text { Diğer müşterilerin beni rahatsız } \\
\text { etmemesi }\end{array}$ & - & - & - & - & - & - &, $053^{* *}$ \\
\hline Servis imkânının olması & - & - & - & - & - & ,032* &, $081^{* *}$ \\
\hline
\end{tabular}


Müşterilerin AVM' lerde kalma süreleri ile AVM de, çarşıda bulunmayan mağazaların olması, ücretsiz dinlenme alanlarının olması, kafe ve restoranların olması, süpermarketin olması, kalabalık olması, kışın soğuktan yazın sıcaktan korunma imkânını vermesi, TV yayınının olması, kolay ulaşılabilir olması ve kaliteli ürünlerin olması \%5 önem seviyesinde ilişkili iken; harcanan paranın karşıı̆ı̆ın alındığı düşüncesini vermesi, güvenlik hizmetinin olması, çok çeşitli mağazalara sahip olması, diğer müşterilerin beni rahatsız etmiyor olması ve servis imkânının olması değişkenleri ile \%10 önem seviyesinde ilişkilidir. Dikkat çeken diğer anlamlı ilişkilerden birkaçı ise; hane geliri ile ücretsiz dinlenme alanlarının olması, hane geliri ile AVM de satış promosyonlarının yapılması, AVM ye gidilen günler ile AVM' nin kalabalık olması, AVM ye gitme sıklı̆ı ile AVM ye kolay ulaşılabilir olması, AVM ye gitme sıklığı ile AVM' nin servis imkânının olması, vb dir. Yapılan ki-kare testinin ardından ilgili verilere korelasyon analizi yapılarak demografik değişkenler ile müşterilerin AVM' yi tercih sebepleri arasındaki ilişkinin varlığı, gücü ve yönü belirlenmiş, sonuçlar Tablo 3 'de gösterilmiştir.

Tablo 3: Korelasyon Analizi Sonuçları

\begin{tabular}{|c|c|c|c|c|c|c|}
\hline & $\stackrel{m}{\infty}$ & 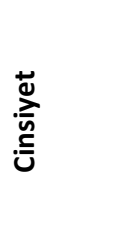 & 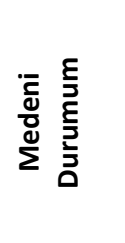 & $\frac{:=}{\bar{E}}$ & 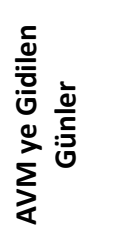 & 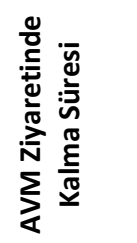 \\
\hline \multirow[t]{2}{*}{ Otopark imkânının olması } &,- 044 &,- 019 &,- 070 & ,009 &,- 136 & 117 \\
\hline & 392 & 717 & 171 & ,856 &, $007 *$ &, $022 * *$ \\
\hline \multirow[t]{2}{*}{ Kafe ve restoranların bulunması } &,- 005 & 143 & ,038 &,- 022 &,- 085 & ,280 \\
\hline & 929 & ,005* & ,452 & 670 &, $096 * * *$ &, $000 *$ \\
\hline \multirow[t]{2}{*}{ Ferah ve kolay gezilebilir olması } &,- 035 & ,004 & ,009 &,- 041 &,- 093 & ,263 \\
\hline & ,493 & 941 & 859 & 417 &, $068 * * *$ &, $000^{*}$ \\
\hline \multirow[t]{2}{*}{ Sinema salonlarının olması } &,- 057 & ,008 &,- 019 &,- 044 & ,031 & 132 \\
\hline & ,265 & ,872 & 706 & 388 & ,544 & ,009* \\
\hline \multirow{2}{*}{$\begin{array}{l}\text { Alışveriş yapan diğer müşterilerin beni } \\
\text { rahatsız etmemesi }\end{array}$} &,- 057 & 105 & ,042 &,- 051 &,- 064 & 093 \\
\hline & ,262 &, $040 * *$ & ,412 & 323 & 213 &, $068 * *$ \\
\hline \multirow[t]{2}{*}{ AVM'de süpermarket bulunması } &,- 025 & 129 & 039 &,- 109 & ,037 & 131 \\
\hline & ,623 &, $011 * *$ & ,449 & ,033** & ,468 &, $010^{*}$ \\
\hline \multirow[t]{2}{*}{ Ürün çeşitliliğinin olması } &,- 110 & ,046 &,- 064 & ,048 &,- 054 & 149 \\
\hline & ,031** & 369 & 209 & 352 & 295 &, $003 *$ \\
\hline \multirow[t]{2}{*}{ AVM'nin temiz ve düzenli olması } &,- 034 &,- 032 &,- 029 &,- 018 &,- 003 &, 028 \\
\hline & ,504 & ,530 & ,568 & 723 & 950 & ,581 \\
\hline \multirow{2}{*}{$\begin{array}{l}\text { Çarşıda bulunmayan mağazalara sahip } \\
\text { olması }\end{array}$} &,- 070 &,- 035 &,- 026 & ,057 &,- 061 & 160 \\
\hline & 168 & ,499 & ,614 & ,269 & ,229 &, $002 *$ \\
\hline \multirow[t]{2}{*}{ Kolay ulaşılabilir olması } &,- 083 & ,042 &,- 110 &,- 013 & ,089 & 142 \\
\hline & 104 & 417 & ,031** & ,806 &, $081 * * *$ &, $005^{*}$ \\
\hline \multirow[t]{2}{*}{ Kaliteli ürünlerin satılması } &,- 070 &,- 006 & ,000 &,- 092 &,- 102 & 149 \\
\hline & 169 & 914 & 1,000 &, $072 * * *$ &, $045 * *$ &, $003^{*}$ \\
\hline \multirow{2}{*}{$\begin{array}{l}\text { AVM'de ücretsiz dinlenme alanlarının } \\
\text { olması }\end{array}$} & 132 & ,068 & ,086 &,- 021 & ,098 & 144 \\
\hline & ,009* & 185 &, $092 * * *$ & 675 &, $054 * *$ &, $005^{*}$ \\
\hline \multirow[t]{2}{*}{ Son moda ürünlerin bulunması } &,- 066 & ,005 & ,000 &,- 045 &,- 077 & 175 \\
\hline & 196 & 926 & 1,000 & 380 & 133 &, $001^{*}$ \\
\hline \multirow[t]{2}{*}{ Ödeme kolaylığının olması } & 019 & ,074 & ,044 &,- 076 &,- 046 & 162 \\
\hline & 713 & 148 & 395 & 138 & 365 & ,001* \\
\hline \multirow[t]{2}{*}{ Harcanan paranın karşılığının alınması } &,- 025 & ,003 & ,096 &,- 023 &,- 076 & 135 \\
\hline & 619 & 959 &, $061 * * *$ & ,652 & 139 & ,008* \\
\hline \multirow[t]{2}{*}{ Eğlenceye yönelik aktivitelerin olması } &,- 065 & ,018 & 110 &,- 083 & ,068 & 086 \\
\hline & 200 & 726 & ,031** & 104 & 181 & $090 * * *$ \\
\hline \multirow[t]{2}{*}{ Çok çeşitli mağazaların olması } &,- 071 & 015 & ,000 &,- 020 &,- 055 & 168 \\
\hline & 163 & ,764 & 1,000 & 697 & ,284 &, $001 *$ \\
\hline
\end{tabular}




\begin{tabular}{|c|c|c|c|c|c|c|}
\hline \multirow[t]{2}{*}{ Satış elemanlarının olumlu davranışları } & ,032 &,- 025 & 075 &,- 118 &,- 038 &,- 019 \\
\hline & ,533 & 628 & 144 &, $021 * *$ & ,462 & 711 \\
\hline \multirow[t]{2}{*}{ Mescit vb. ibadethanelerin olması } &,- 102 & 120 & ,000 &,- 008 & 058 & ,086 \\
\hline &, $047^{* *}$ & ,019** & 1,000 & ,869 & ,256 & ,091*** \\
\hline \multirow{2}{*}{ Tarzıma uygun olması } & $-0,073$ & 0,030 & $-0,062$ & 0,055 & $-0,085$ & 0,160 \\
\hline & 150 & ,559 & ,228 & ,280 &, $097 * * *$ &, $002^{*}$ \\
\hline \multirow{2}{*}{$\begin{array}{l}\text { AVM'de çalınan müziklerin sevdiğim } \\
\text { tarzda olması }\end{array}$} &,- 091 & ,061 & ,050 &,- 062 & 021 & 007 \\
\hline &, $074 * * *$ & ,230 & 330 & 227 & 686 & ,887 \\
\hline \multirow[t]{2}{*}{ Yürüyen merdivenlere sahip olması } &,- 044 & 124 & ,076 &,- 152 &,- 006 & 112 \\
\hline & 391 &, $015^{* *}$ & 139 & ,003* & 914 &, $028 * *$ \\
\hline \multirow[t]{2}{*}{ Işıklandırmanın iyi olması } &,- 073 & 126 & 108 &,- 146 &,- 008 & ,095 \\
\hline & 154 &, $013 * *$ &, $034 * *$ &, $004 *$ & ,881 &, $064 * * *$ \\
\hline \multirow[t]{2}{*}{ Evime yakın olması } &,- 014 & ,084 &,- 071 &,- 030 &,- 075 & ,026 \\
\hline & 781 &, $098 * * *$ & 166 & ,563 & 141 & 606 \\
\hline \multirow{2}{*}{$\begin{array}{l}\text { AVM içerisinde aranan yerin kolay } \\
\text { bulunması }\end{array}$} & ,017 & ,083 & ,018 & ,011 & ,002 & 109 \\
\hline & 743 & 106 & 722 & ,826 & 966 &, $033 * *$ \\
\hline \multirow[t]{2}{*}{ Ünlü mağazaların bulunması } & ,033 &,- 046 & ,061 & ,034 &,- 023 & 104 \\
\hline & ,519 & ,369 & 230 & ,502 & 648 &, $042 * *$ \\
\hline \multirow[t]{2}{*}{ AVM'nin büyük olması } &,- 099 & ,017 & ,077 &,- 075 & ,002 & ,038 \\
\hline &, $053 * * *$ & 744 & 131 & 143 & 976 & ,455 \\
\hline \multirow[t]{2}{*}{ Yüksek imaja sahip olması } &,- 077 &,- 045 & ,070 &,- 080 &,- 015 & ,093 \\
\hline & 132 & 377 & 172 & 116 & 771 & ,069*** \\
\hline \multirow[t]{2}{*}{ Servis imkânının olması } & ,036 & ,011 &,- 031 &,- 036 &,- 093 &,- 020 \\
\hline & ,475 & ,832 & ,540 & ,475 &, $068 * * *$ & 696 \\
\hline \multirow[t]{2}{*}{ TV Yayınının olması } &,- 038 &,- 029 & ,073 &,- 089 &,- 046 &,- 072 \\
\hline & ,458 & ,568 & 152 &, $082 * * *$ & ,367 & 160 \\
\hline \multirow[t]{2}{*}{ İçerisinde ATM olması } & ,029 & ,028 & ,046 & ,023 & 049 & 144 \\
\hline & ,577 & ,586 & 371 & 656 & ,337 &, $005^{*}$ \\
\hline \multirow{2}{*}{$\begin{array}{l}\text { Kışın soğuktan, yazın sıcaktan } \\
\text { korunmak için }\end{array}$} & ,061 & 128 & ,046 &,- 002 & ,015 & , 168 \\
\hline & 231 &, $012^{* *}$ & 370 & 962 & 768 &, $001 *$ \\
\hline
\end{tabular}

Tablo 3’ de gösterilen korelasyon değerleri için; *, \%1 önem seviyesini, **, \%5 önem seviyesini, *** , \%10 önem seviyesini temsil etmektedir. \%1 önem seviyesi yapılan analizin \%99 güven aralığında, \%5 önem seviyesi \%95 güven aralığında ve \%10 önem seviyesi \%90 güven aralığında olduğunu ifade etmektedir.

Yaş değişkeni ile;

- $\quad$ AVM lerde ürün çeşitliliğinin olması arasında \%5 önem seviyesinde 0,110 luk negatif yönlü,

- $\quad$ AVM lerde ücretsiz dinlenme alanlarının olması arasında \%1 önem seviyesinde 0,132' lik pozitif yönlü,

- AVM lerde mescit ve ibadethanelerin olması arasında \%5 önem seviyesinde 0,102 'lik negatif yönlü zayıf bir ilişki bulunmaktadır.

Cinsiyet değişkeni ile;

- Alışveriş yapan diğer müşterilerin beni rahatsız etmemesi arasında \%5 önem seviyesinde pozitif yönlü 0,105 oranında,

- $\quad$ AVM de süpermarket bulunması arasında \%5 önem seviyesinde 0,129' luk pozitif yönlü zayıf bir ilişki vardır.

Medeni durum değişkeni ile;

- Eğlenceye yönelik aktivitelerin olması arasında \%5 önem seviyesinde yüzde 0,11' lik pozitif yönlü zayıf,

- $\quad$ AVM de ücretsiz dinlenme alanlarının olması arasında \%10 önem seviyesinde pozitif yönlü \% 86' lık kuvvetli ,

- Kolay ulaşılabilir olması arasında \%5 güven aralığında 0,108 lik negatif yönlü \%11'lik zayıf bir ilişki vardır.

AVM'ye gidilen günler değişkeni ile;

- Ferah ve kolay gezilebilir olması değişkeni arasında \%10 önem seviyesinde negatif yönlü 0,093 lük zayıf bir ilişki vardır. 
AVM ziyaretinde kalma süresi değişkeni ile;

- Kafe ve restoranların bulunması değişkeni arasında \%1 güven aralığında pozitif yönlü \%28 lik zayıf ilişki,

- Ferah ve kolay gezilebilir olması arasında \%1 güven aralığında 0,263 ‘ük pozitif yönlü zayıf ilişki,

- Yürüyen merdiven olması değişkeni arasında \%5 güven aralığında \%11 lik pozitif yönlü zayıf bir ilişki

- Mescit ve ibadethanelerin olması değişkeni arasında \%10 güven aralığında 0,086' lık pozitif yönlü zayıf ilişki,

- Sinema salonlarının olması değişkeni arasında \% 1 güven aralığında pozitif yönlü \%13 oranında zayıf ilişki,

- Kışın soğuktan yazın sıcaktan korunma imkânı vermesi değişkeni arasında \%1 güven aralığında pozitif yönlü \%16 lık zayıf bir ilişki,

- Çok çeşitli mağazaların olması değişkeni arasında \%1 güven aralığında pozitif yönlü yaklaşık \%17 lik zayıf bir ilişki,

- Son moda ürünlerin bulunması değişkeni arasında \%1 güven aralığında pozitif yönlü, 0,175 oranında zayıf bir ilişki vardır.

\section{SONUÇ}

Insanoğlunun temel eylemlerinden olan alışveriş, önceleri şehir merkezlerinde meydana gelen sosyal bir olgu iken zamanla sosyal yaşamda meydana gelen farklılıklar, artan gelir, kültürel değişim ve insanların ihtiyaçlarını karşılamaya yetecek kadar zaman bulamaması, işletmeleri ve insanları perakendecilerin toplu halde tek bir merkezden yönetildiği AVM' lere yöneltmiştir. Artan AVM sayısı karşısında cadde mağazacılığı yapan işletmelerin rekabet gücü azalmış ve rekabet üstünlüğünü kısmen AVM mağazacılığına kaptırmışlardır. Bu çalışmada müşterilerin AVM' leri tercih etme sebepleri araştırımıştır. Analiz sonucu ulaşılan örnekleme ait demografik özellikler ve frekans dağıımları şu şekildedir; araştırmaya katılıp anket sorularını cevaplayan katııımcıların yaklaşık \%98'i 21-30 yaş aralığında olmakla birlikte yaklaşık \%64' ü bayandır. Katılımcıların yaklaşık \%96 sı bekar, \%92'si üniversite mezunudur ve gelirleri \%23,4 oranla 2001-3000 TL arasındadır. Tüketicilerin AVM leri ziyaret ettikleri günler $\% 53,5^{\prime}$ lik oranla belirli bir gün değilken, \% $30,9^{\prime}$ luk oranla hafta sonlarıdır ve katılımcıların \%31,4' ü AVM de 31-60 dakika arasında vakit geçirmektedir.

Araştırma sonuçları değerlendirildiğinde, AVM ye gitme sıklığı ile AVM ye kolay ulaşılabilir olması gibi AVM'lerin, tüketicinin istek ve beklentilerine fiziksel olarak cevap vermesi gerektiği saptanmıştır. Ayrıca AVM' lerin, değişen sosyo kültürel yapı ile ilişkili olarak “AVM ye gidilen günler ile AVM nin kalabalık olması” gibi kendiliğinden sahip olduğu üstünlüğünü muhafaza etmesi gerektiği görülmüştür. Yapılan korelasyon analizi sonucunda, yaş değişkeni ile AVM' lerde ücretsiz dinlenme alanlarının olması arasında pozitif yönlü bir ilişki saptanmıştır. Cinsiyet değişkeni ile alışveriş yapan diğer müşterilerin rahatsız etmemesi ve AVM'de süpermarket bulunması arasında pozitif yönlü bir ilişki saptanmıştır. Medeni durum değişkeni ile eğlenceye yönelik aktivitelerin olması, AVM 'de ücretsiz dinlenme alanlarının olması arasında pozitif yönlü ilişki saptanmıştır. Yine AVM ziyaretinde kalma süresi değişkeni ile kafe ve restoranların bulunması, ferah ve kolay gezilebilir olması, yürüyen merdiven olması, mescit ve ibadethanelerin olması, sinema salonlarının olması, kışın soğuktan yazın sıcaktan korunma imkânı vermesi, çok çeşitli mağazaların olması ve son moda ürünlerin bulunması arasında pozitif yönlü ilişki saptanmıştır.

\section{KAYNAKÇA}

Akat, Ö. (2004). Uluslararası Pazarlama Karması ve Yönetimi, Ekin Kitabevi, Bursa.

Alkibay, S. Doğan, T. Hoşgör, Ş. (2007). Alışveriş Merkezleri ve Yönetimi, Siyasal Kitabevi , Ankara

Altunışık, R. Mert, K. (2007). Tüketicilerin Alışveriş Merkezlerindeki Satın Alma Davranışları Üzerine Bir Saha Çalışması: Tüketiciler Kontrolü Yitiriyor mu?

Arslan,F.M. (2004). Mağazacılıkta Atmosfer, Derin Yayınları, İstanbul.

Aydın, K. (2007). Perakende Yönetimin Temelleri, Nobel Yayınları, Ankara.

Azhari, N. F. N, Salam, H. Hasbullah, M. N. (2012). Baby care room in shopping malls: Accessibility to Malaysian public. Procedia - Social and Behavioral Sciences, 35, 531- 538.

Beylü, Eke. (1982). Tüketimin Sosyolojik Anlamı ,Sosyal Siyaset Konferansları (Prof.Dr. Orhan Tuna'ya Armağan ), İstanbul: İstanbul Üniversitesi Yayınları. 413-428

Birol, G. (2005) , "An Alternative Approach for Analysis of Traditional Shopping Spaces and A Case Study on Balıkesir", Trakya University Journal of Science, 6, (1), 63-75.

David S. R. (2007). Retail Location Analysis in Practice, Research Review, 14, (2), 73-77.

Ekinci, I. Aktaş, T. Adil, I. Varlı, I. (1999). Alışveris Merkezler ve Zincirler, Power.

Kotler, P. Kevin, K. (1997), Marketing Management, Twelfth Edition, Prentice Hall International Inc., New Jersey, USA, p.729.

Kotler, P. (2000). Pazarlama Yönetimi, 10. baskıdan çeviren: Nejat Muallimoğlu, Beta Yayınları, İstanbul.

Levy, M. Weitz, B.A. (2004). Retailing Management, 5th Edition, Mc Graw Hill, Irwin/Boston 
Odabaşı Y. Barış, G. (2002). Tüketici Davranışı, İstanbul: Kapital Medya Hizmetleri

Önbilgin, T. Uzun, i. (2002). Alışveriş merkezleri ve atriumlar. Ege Mimarlık . 23-26. Erişim Tarihi: 23.01.2017. http://www.egemimarlik.org/40-41/40-41-7.pdf

Pekgüleç, E. (2003). Tüketici Satın Alma Modelleri ve Bursa Bölgesinde Bir Uygulama. Uludağ Üniversitesi, Sosyal Bilimler Enstitüsü, Yayımlanmamış Yüksek Lisans Tezi, Bursa.

Süer, D. Sayar, Y. (2002). Küresel Sermayenin Yeni Tüketim Mekânları, Mimarlık ve Tüketim içinde, Boyut Yayın, İstanbul.

Tek, Ö. B. (1999). Pazarlama İlkeleri: Global Yönetimsel Yaklaşım, Türkiye Uygulamaları, Beta Basım Yayım Dağıtım, İstanbul.

Torlak Ö. (2007). Tüketicilerin Değişen Hayat Tarzları Postmodern Dünyada Tüketimi Yeniden Anlamlandıracak Yeni Müşteri , (Editörler: Remzi Altunışık ve Ömer Torlak), Hayat Yayınları, İstanbul.

White, R., Sutton, A. (2001) "Social Planning for Mall Redevelopment: an Australian Case Study", Local Environment, 6, (1), 65-80 